\title{
DOTACJA INWESTYCYJNA JAKO NARZĘDZIE MODYFIKACJI MODELU BIZNESU
}

Z a r y s t r e ś c i: Dotacje inwestycyjne były w ostatnich latach popularnym instrumentem wsparcia małych i średnich przedsiębiorstw w ramach środków pomocowych Unii Europejskiej. Pomoc ta miała na celu dokonanie diametralnych zmian w prowadzonych biznesach. Jeśli uznać, iż model biznesu przesądza o logice prowadzonego przedsięwzięcia, to przyjąć należy, iż pomoc ta powinna zrekonfigurować modele biznesu w badanych przedsiębiorstwach. Dopiero wtedy można przesądzać o długotrwałych, pozytywnych efektach udzielonego wsparcia.

S ł o w a k 1 u c z o w e: model biznesu; małe i średnie przedsiębiorstwo; dotacja inwestycyjna

K l a s y fik a c j a J E L: M20.

\section{WSTĘP}

Działalność gospodarcza zawsze prowadzona była według konkretnego modelu biznesu. Jednakże dopiero w ostatnich kilkunastu latach nastąpił intensywny wzrost zainteresowania tą koncepcją, zarówno ze strony badaczy naukowych, jak i praktyków zarządzania. Definicji i podejść do modeli biznesu w literaturze przedmiotu jest cały szereg. Mimo tego, wciąż nie ma

* Adres do korespondencji: Marian Oliński, Uniwersytet Warmińsko-Mazurski w Olsztynie, Wydział Nauk Ekonomicznych, Katedra Organizacji i Zarządzania, ul. M. Oczapowskiego 4, 10-719 Olsztyn, e-mail: molinski1@wp.pl. 
konsensusu, co do jego znaczenia. Pogłębiona analiza literatury przedmiotu pozwala na wskazanie trzech elementów wspólnych, składających się na model biznesu tj.:

- Produkt/usługa proponowana klientom, czyli propozycja wartości, będąca odpowiedzią na pytanie: kto jest naszym klientem i co mu oferujemy (jaką wartość).

- Sposób organizacji przedsiębiorstwa w celu dostarczenia produktu/ usługi klientom, który jest z kolei odpowiedzią na pytanie: jak dostarczamy tę wartość klientowi (uwzględnić należy nie tylko własny łańcuch tworzenia wartości, ale również rolę dostawców i partnerów w jej tworzeniu).

- Model przychodu.

Niektórzy autorzy skupiają się jednakże na wybranych przez siebie komponentach. Przykładowo H. Chesbrough i R. S. Rosenbloom, koncentrują się na modelu przychodu (Chesbrough, Rosenbloom, 2002, s. 529555), czy C. Zott i R. Amitt, którzy główną uwagę poświęcają systemowi połączonych i współzależnych działań, określających sposób prowadzenia działalności biznesowej ze swoimi klientami, partnerami i dostawcami (Zott, Amit, 2008, s. 1-26). Autorzy niniejszego opracowania, w ramach przeprowadzonych badań, koncentrowali się na statycznym podejściu do modeli biznesu. Podejście to umożliwia budowę typologii i analizę zależności między stosowanym modelem a wynikami przedsiębiorstwa. Wykorzystany w badaniach szablon modelu biznesu A. Osterwaldera i Y. Pigneura jest najbardziej statycznym podejściem, w którym zależności w ramach poszczególnych elementów modelu biznesu prezentowane są szczątkowo oraz praktycznie brak jest informacji o mechanizmach wzmacniających i regulujących, oddziałujących na funkcjonowanie przedsiębiorstwa (Doligalski 2014, s. 107). Jego podstawową zaletą jest to, że w stosunkowo łatwy sposób dokonać można wizualizacji modelu biznesu. $Z$ kolei dynamiczne podejście do modeli biznesu to prezentacja zachodzących w przedsiębiorstwie sprzężeń zwrotnych. W tym przypadku budowa modelu biznesu stanowi dużo większe wyzwanie, choć jego analiza prowadzić może do bardziej nowatorskich spostrzeżeń niż w modelu statycznym.

\section{METODYKA BADAŃ}

Badaniami objęte zostały podmioty, które uzyskały wsparcie w formie dotacji inwestycyjnej w ramach Regionalnego Programu Operacyjnego 
Warmia i Mazury na lata 2007-2013 (badania przeprowadzono w połowie 2014 roku metodą ankiety bezpośredniej). Analizowane były wszystkie działania polegające na udzielaniu dotacji mikro- i małym przedsiębiorstwom:

- Poddziałanie 1.1.5 - „Wsparcie MŚP - promocja produktów i procesów przyjaznych dla środowiska".

- Poddziałanie 1.1.7 - „Dotacje inwestycyjne dla mikroprzedsiębiorstw i sektora MŚP w zakresie innowacji i nowych technologii”.

- Poddziałanie 1.1.9 - „Inne inwestycje w przedsiębiorstwa”.

Ze względu na fakt, iż badania dotyczą efektów, jakie pomoc w formie dotacji wywarła na sektor MSP z obszarów wiejskich na Warmii i Mazurach, dobierane były te podmioty, które najwcześniejszej uzyskały pomoc. W podmiotach takich można bowiem zdiagnozować efekty przyznanej pomocy. Zgodnie $\mathrm{z}$ regułą $\mathrm{n}+2$ podmioty miały maksymalnie dwa pełne lata na zrealizowanie inwestycji, na którą podpisały umowę o dotację. Biorąc pod uwagę ten fakt oraz regułę trwałości projektów (3 lata po zakończeniu projektu), przedsiębiorstwom, które podpisały umowę w latach 2008-2010 (2008 był pierwszym rokiem podpisywania umów), skończył się (lub mógł się skończyć, np. w przypadku 2010 roku - jeśli w tym samym roku zamknięto cały proces) okres trwałości. Można więc zbadać, co działo się w tym okresie. Rekordów spełniających te kryteria jest 82, tzn. przyznano 82 dotacje dla MSP na obszarach wiejskich. Zamierzano zatem objąć badaniem wszystkie przedsiębiorstwa tego typu. Jednakże ze względu na minimalną założoną liczbę przedsiębiorstw zbadanych (60 jednostek), okazało się, że z grupy 82 jednostek nie da się uzyskać tego wyniku. Po pierwsze, liczba rekordów nie jest tożsama z liczbą przedsiębiorstw, ponieważ niektóre przedsiębiorstwa brały więcej niż jedną dotację w tych latach (są nawet przypadki składania na ten sam konkurs kilku wniosków i uzyskania więcej niż jednej dotacji przez przedsiębiorstwo). Po tego rodzaju weryfikacji liczba przedsiębiorstw z 82 zmniejszyła się do 70. Poza tym liczyć się należy z odmową współpracy $\mathrm{w}$ trakcie badań ankietowych przez przedsiębiorstwo - badania te bezpośrednio dotyczą wyników ekonomicznych

1 Działanie 1.1.6, pomimo tego, iż polegało na przyznawaniu dotacji inwestycyjnych warmińsko-mazurskim przedsiębiorstwom, zostało pominięte ze względu na fakt, iż polegało ono na udzielaniu pomocy jedynie dużym przedsiębiorstwom (za duże przedsiębiorstwo uznaje się podmioty, które nie spełniają kryterium mikro, małego i średniego przedsiębiorcy według wspomnianej już definicji zawartej w ustawie z 2 lipca 2004 r. o swobodzie działalności gospodarczej). 
przedsiębiorstw - są to więc dane newralgiczne, które przedsiębiorcy niechętnie ujawniają. Dlatego okazało się koniecznością dobranie podmiotów, które podpisały umowy w 2011 roku. Takich umów na dotacje w 2011 roku podpisało 27 przedsiębiorstw. Są to podmioty, których okres trwałości projektu nie zakończył się, ale które zakończyły proces inwestycyjny. W tym przypadku również zaobserwować będzie można efekty ekonomiczne przyznanej pomocy.

Tabela 1. Zestawienie dotacji otrzymanych w latach 2008-2011 w województwie warmińsko-mazurskim na obszarach wiejskich

\begin{tabular}{c|cccc|c} 
& 2008 & 2009 & 2010 & 2011 & $\begin{array}{c}\text { Suma } \\
\text { wiersza }\end{array}$ \\
\hline $\begin{array}{c}\text { Podpisane umowy } \\
\text { na dotacje }\end{array}$ & 1 & 29 & 52 & 28 & 110 \\
$\begin{array}{c}\text { Przedsiębiorstwa, } \\
\text { które podpisały } \\
\text { umowy }\end{array}$ & 1 & 23 & 46 & 27 & 97 \\
$\begin{array}{c}\text { Odmowa udziele- } \\
\text { nia informacji }\end{array}$ & 0 & 2 & 8 & 6 & 16 \\
$\begin{array}{c}\text { Przedsiębiorstwo } \\
\text { nie istnieje }\end{array}$ & 0 & 2 & 5 & 0 & 7 \\
$\begin{array}{c}\text { Przedsiębiorstwa, } \\
\text { które wypełniły } \\
\text { kwestionariusz }\end{array}$ & 1 & 19 & 33 & 21 & 74 \\
\hline Z
\end{tabular}

Źródło: opracowanie własne na podstawie badań.

W badaniach posłużono się tzw. modelem biznesu „Canvas” zaproponowanym przez A. Osterwalder i Y. Pigneur (Osterwalder, Pigneur, 2010, s. 20-21). Model ten zawiera dziewięć elementów składowych: segmenty klientów, propozycje wartości, kanały, relacje z klientami, strumienie przychodów, kluczowe zasoby, kluczowe działania, kluczowych partnerów, strukturę kosztów. W związku z przyjętym schematem (szablonem) modelu nasuwa się pytanie, które z dziewięciu wymienionych elementów zmieniało się najczęściej pod wpływem otrzymanego wsparcia i jakie to ma konsekwencje dla funkcjonowania i rozwoju badanych przedsiębiorstw. Na potrzeby niniejszych badań przyjęto, iż otrzymane wsparcie w dużym stopniu przyczyniło się do analizowanych rezultatów, bowiem według badań tylko 
3 przedsiębiorstwa zdecydowałyby się na realizację projektu rozwojowego ze środków własnych, nawet gdyby nie otrzymały wsparcia. Natomiast 47 przedsiębiorstw (63,5\% badanych podmiotów) od razu odrzucało możliwość zrealizowania projektu (nawet w ograniczonej formie czy przy zdobyciu finansowania zwrotnego).

\section{ZMIANY W POSZCZEGÓLNYCH SKŁADNIKACH MODELU BIZNESU}

Aby można było przesądzić o stopniu rekonfiguracji badanych modeli biznesu, konieczne jest zidentyfikowanie zmian w poszczególnych elementach składowych tychże modeli. Pierwszy z elementów składowych to segmenty klientów. Ten element modelu biznesu wskazuje różne grupy ludzi i organizacje, do których przedsiębiorstwo stara się dotrzeć i które chce obsługiwać. Segmentacja polega na ustaleniu, które grupy nabywców powinny być zainteresowane zakupem proponowanego produktu czy usługi (Lambert, 1999, s. 216-217). Jest to ważny proces zarządczy w konfigurowaniu modelu biznesu, przesądza bowiem o kształcie (w wyniku dopasowania) innych elementów (np. kanałów). W związku z tym faktem, nasuwa się pytanie, na ile otrzymana pomoc i związane z nią inwestycje wpłynęły na potrzebę dokonania (lub przeorientowania) segmentacji. Okazuje się, że tylko 2 przedsiębiorstwa dokonały zmian w tym obszarze i zaczęły prowadzić bardziej świadomą politykę w tym zakresie. Ważne dla każdego przedsiębiorstwa są także plany ekspansji oraz ich realizacja.

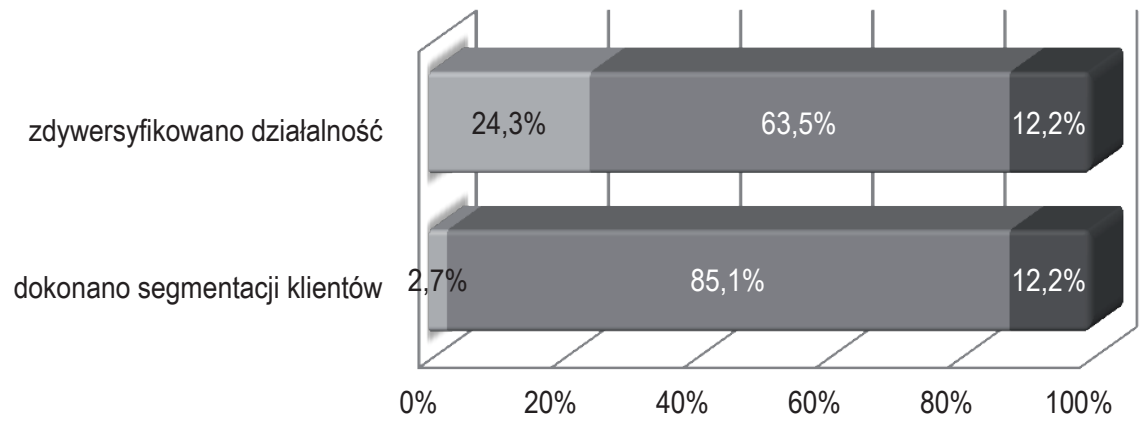

$\square$ tak $\square$ nie $\square$ nie dotyczy

Rysunek 1. Segmenty klientów

Źródło: opracowanie własne na podstawie badań. 
Zatem na ile otrzymana pomoc w postaci dotacji inwestycyjnej pozwoliła badanym przedsiębiorstwom na zdywersyfikowanie działalności (tzn. rozpoczęcie obsługiwania dodatkowego segmentu klientów)? Okazuje się, że w tym obszarze otrzymane wsparcie miało dużo większe znaczenie (niemal co czwarte przedsiębiorstwo dokonało takiej ekspansji, tzn. zaczęło obsługiwać klientów z innego obszaru geograficznego, inna grupę dochodową, wiekową itd.).

Propozycja wartości jest uznawana za najważniejszy element modelu biznesu. Element ten można uznać za podstawę ontologiczną koncepcji modelu biznesu - występuje bowiem w większości definicji proponowanych przez autorytety naukowe zajmujące się problematyką modeli biznesu (np. Aspara, Lamberg, Laukia, Tikkanen, 2013, s. 459; Falencikowski, 2013, s. 37; Cyfert, Krzakiewicz, 2011, s. 101; Amit, Zott, 2010, s. 217; Baden-Fuller, Morgan, 2010, s. 157; Teece, 2010, s. 173; Casadesus-Masanell, Ricart, 2010, s. 196; Wikström, Artto, Kujala, Söderlund, 2010, s. 834; Johnson, Christensen, Kagermann, 2008, s. 51-520; Chesbrough, Rosenbloom, 2002, s. 533-534; Magretta, 2002, s. 87; Osterwalder, Pigneur, 2002, s. 2). Na potrzeby niniejszych badań propozycję wartości podzielono na elementy o charakterze ilościowym oraz jakościowym. Przykładowo, do pierwszej grupy można było zaliczyć cenę (tzn. w wyniku realizacji danego przedsięwzięcia udało się obniżyć ceny). Jako przykład w drugiej grupie można podać estetykę (tzn. poprawa w estetyce oferowanego produktu). Respondenci mieli w kwestionariuszu podane przykłady, mogli także dodać własne cechy. Uzyskana pomoc pozwoliła większości przedsiębiorcom na zmiany w propozycji wartości (i to zarówno tych o charakterze ilościowym, jak i jakościowym - przy czym przeważają zmiany w wartościach o charakterze ilościowym - aż 48 przedsiębiorstw dokonało takich zmian).

Kanały stanowią element modelu biznesu, który wskazuje, w jaki sposób firma komunikuje się z poszczególnymi segmentami swoich klientów oraz przekazuje im własną propozycję wartości (Osterwalder, Pigneur, 2010, s. 30). Wachlarz rodzajów kanałów, z jakich mogą korzystać przedsiębiorstwa, jest szeroki. Generalnie kanały można podzielić na własne (np. własny sklep) lub partnerskie (np. hurtownia). W większości przypadków analizowana pomoc nie wpłynęła na rekonfigurację tego elementu składowego modelu biznesu (57 przedsiębiorstw w wyniku realizacji projektu nie nawiązało kontaktów z partnerami, czyli np. hurtownikami, sklepami partnerskimi itd., a 53 podmioty nie utworzyły ani nie zmodyfikowały własnych kanałów, np. organizacja własnej sprzedaży przez internet itp.). 
elementy o charakterze jakościowym

elementy o charakterze ilościowym

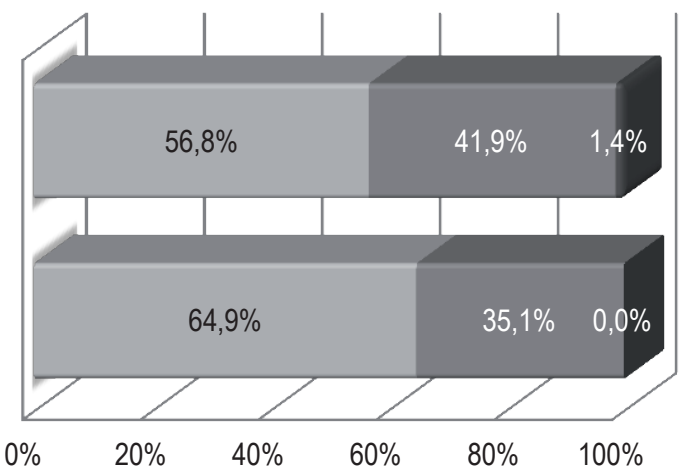

$\square$ tak $\square$ nie $\square$ nie dotyczy

Rysunek 2. Propozycja wartości

Źródło: opracowanie własne na podstawie badań.

nawiązano kontakty z partnerami

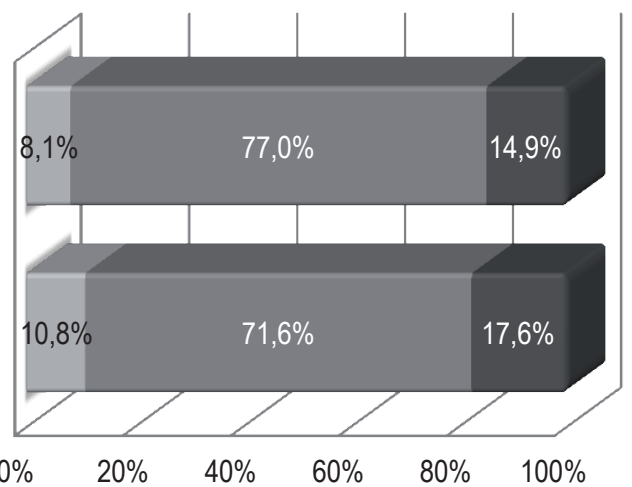

$\square$ tak $\square$ nie $\square$ nie dotyczy

Rysunek 3. Kanały

Źródło: opracowanie własne na podstawie badań.

Relacje stają się podstawą działań strategicznych przedsiębiorstwa (Zakrzewska-Bielawska 2014, s. 20-21). Relacje z klientami decydują o tworzeniu wartości zarówno dla klienta, jak i dla przedsiębiorstwa, osiąganej między innymi przez długookresową współpracę opartą na bezpośrednich, dwustronnych, stałych i silnych związkach z klientem (Petrykowska, 2013, s. 8). Relacje przesądzają o zatrzymywaniu klientów, ale także ich pozyskiwaniu, dlatego są uwzględnianie w większości koncepcji dotyczących 
modeli biznesu. Jednakże ten element nie został zbytnio wzmocniony w badanych przedsiębiorstwach. Najwięcej zmian dotyczyło współtworzenia produktów wraz klientami. Wiele przedsiębiorstw na świecie zaczęło eksperymentować ze współtworzeniem wartości, wykorzystując relacje z klientami (Prahalad, Ramaswamy, 2005, s. 43). Nie jest to więc żadna nowość niezależnie od skali (świata, kraju czy regionu). Niemniej jednak dla badanych przedsiębiorstw jest to element innowacyjny, wpisujący się w nowoczesne trendy. Dlatego za korzystny należy uznać fakt, iż wzrost znaczenia współtworzenia w oparciu o relacje z klientami jest największy spośród innych elementów wchodzących w tę część składową modelu biznesu. Natomiast za niekorzystny należy uznać fakt, iż dotyczy to zaledwie 10 przedsiębiorstw na 74 przebadane podmioty.

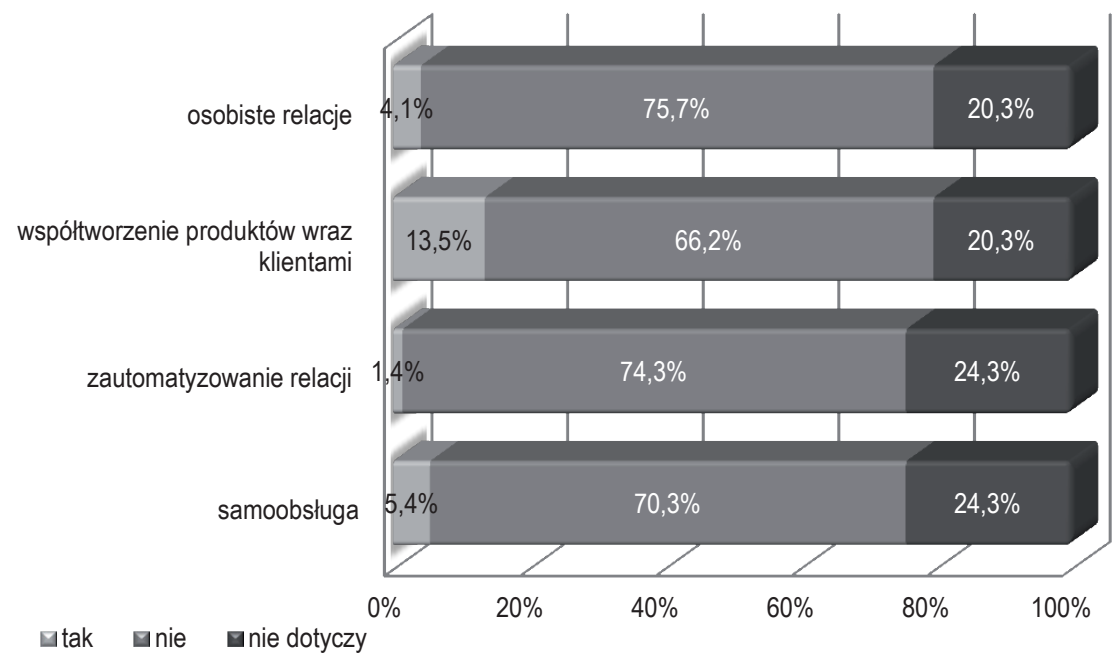

Rysunek 4. Relacje z klientami

Źródło: opracowanie własne na podstawie badań.

Strumienie przychodów stanowią o ilości i rodzaju środków finansowych generowanych przez przedsiębiorstwo (Osterwalder, Pigneur, 2010, s. 34). Strumienie przychodów generować można na różne sposoby, niemniej jednak żaden z rodzajów strumieni przychodów nie został zmodyfikowany (ani tym bardzie wykreowany) w wyniku otrzymanej pomocy. Przedsiębiorcy nie wprowadzili opłaty za korzystanie (tzw. opłaty abonenckiej), z udzielania licencji, nie wprowadzono prowizji z tytułu pośrednictwa itd. Reasumując, otrzymana pomoc nie zmieniła sposobów uzyskiwania 
przychodów. Głównym sposobem jest tu uiszczanie opłaty przez klientów w tradycyjny sposób (bezpośrednio za nabyte produkty lub wyświadczone usługi i nic się w tym zakresie nie zmieniło).

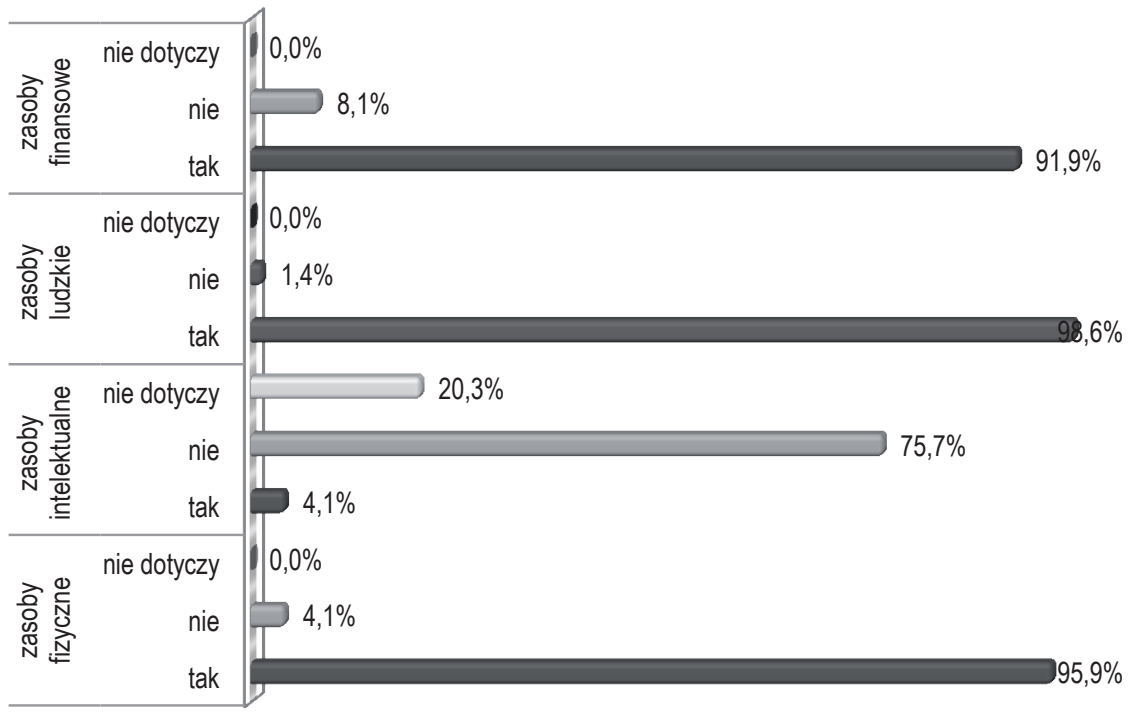

Rysunek 5. Kluczowe zasoby

Źródło: opracowanie własne na podstawie badań.

Kolejną analizowaną składową są kluczowe zasoby. Do kluczowych zasobów przedsiębiorstwa zaliczani są ludzie, pieniądze, zasoby rzeczowe (rzeczy, budynki), jak i zasoby intelektualne (np. wartości niematerialne i prawne). Zasoby są zaliczane jako element składowy modelu biznesu, ponieważ każdy biznes potrzebuje zasobów, aby wytworzyć wartość dla klienta (stanowiącej, jak zostało wspomniane, podstawową kategorię ontologiczną modelu biznesu). Właśnie zasoby są tą składową, która zmieniła się najbardziej wśród wszystkich elementów modeli biznesu. W największym stopniu dotyczyło to zasobów ludzkich (w prawie wszystkich badanych przedsiębiorstwach) oraz zasobów rzeczowych. Poprawa w zasobach ludzkich spowodowana jest faktem, iż dodatkowe zatrudnianie ludzi było jednym z ważniejszych kryteriów przyznawania dotacji (tzn. można było za ten obszar uzyskać najwięcej punktów, co z kolei przesądzało o miejscu na liście rankingowej przy przyznawaniu wsparcia). Poza tym dokonane inwestycje w majątek trwały wymagało poszerzenia wiedzy i zdobycia 
nowych umiejętności przez dotychczasowych pracowników (np. obsługa i konserwacja nowoczesnych maszyn i urządzeń). Wszystko to miało duży wpływ na prezentowane w niniejszym artykule wyniki badań. Nie powinna dziwić natomiast duża zmiana w zasobach fizycznych (wspomniane inwestycje w majątek trwały, które dominowały w realizowanych projektach).

Kluczowe, czyli najważniejsze działania, które przedsiębiorstwo musi realizować, aby z powodzeniem prowadzić biznes, także uległy dość poważnym zmianom (choć nie tak zasadniczym jak poprzednio analizowany element). Najwięcej zmian zaszło w procesie produkcji (nowe technologie, sposoby produkcji, procesy świadczenia usług itd.). Zmiany w zarządzaniu łańcuchem dostaw czy też podejścia w rozwiązywaniu problemów (głównie dla sektora usługowego) miały w tym obszarze o wiele mniejsze znaczenie. Wpływ na ten stan rzeczy miała zapewne dominacja sektora produkcyjnego i charakter realizowanych inwestycji rozwojowych.

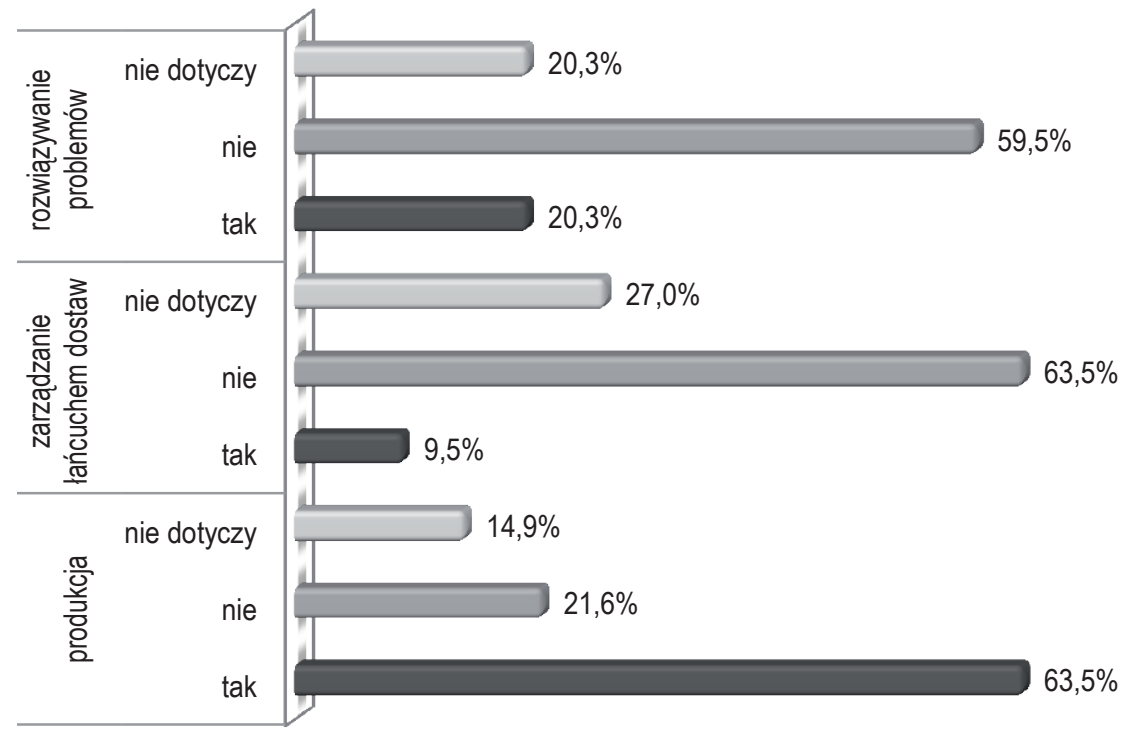

Rysunek 6. Kluczowe działania

Źródło: opracowanie własne na podstawie badań.

Kluczowi partnerzy to element modelu biznesu opisujący sieć dostawców i współpracowników, od których zależy sprawne funkcjonowanie przedsiębiorstwa (Osterwalder, Pigneur, 2010, s. 42). Otrzymana pomoc wpłynęła w umiarkowanym stopniu na poziom współpracy i/lub poprawę 
kontaktów z innymi współpracującymi przedsiębiorstwami (14 podmiotów na 74). Podobne wyniki odnoszą się w stosunku do dostawców. Natomiast relacje z pozostałymi interesariuszami (np. inwestorami) praktycznie nie uległy zmianom. Potrzeba integracji działań w różnych sferach ludzkiej aktywności istniała od zawsze (Olesiński, 2010, s. 68), jednakże dające się obecnie zaobserwować przechodzenie przedsiębiorstw od struktur hierarchicznych do struktur sieciowych, zarówno o charakterze pionowym, jak i poziomym, wzmaga potrzebę poszerzenia perspektywy analizy uczenia się organizacji o wymiar międzyorganizacyjny (Nogalski, Karpacz, Wójcik-Karpacz, 2014, s. 149). Dlatego też, biorąc pod uwagę, iż poszukiwanie synergii z relacji współdziałania jest jedną z wytycznych sprawnego działania (Stańczyk-Hugiet, 2013, s.74), fakt słabego wpływu otrzymanej pomocy na poprawę relacji z kluczowymi partnerami jest niewątpliwie zjawiskiem niekorzystnym.

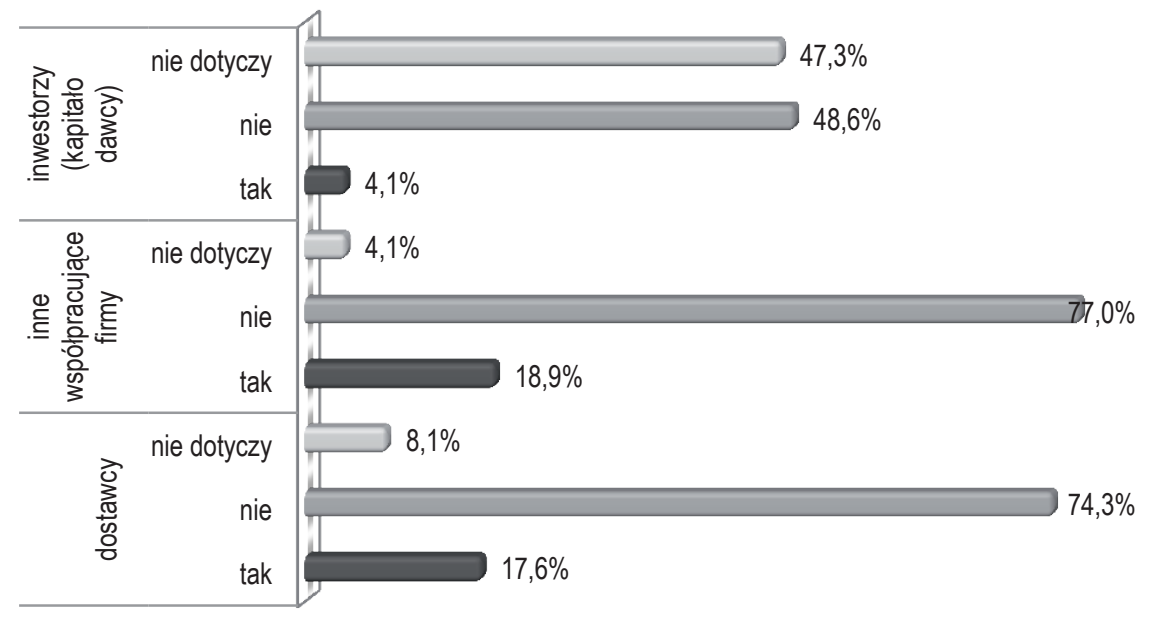

Rysunek 7. Kluczowi partnerzy

Źródło: opracowanie własne na podstawie badań.

Wszystkie działania podejmowane przez organizację skutkują powstaniem kosztów (Cyfert, 2012, s. 46), dlatego model biznesu powinien dawać odpowiedź na pytania dotyczące struktury, jak i wielkości kosztów. Jedną z częściej stosowanych typologii kosztów (np. stosowanym szeroko w rachunkowości zarządczej) jest podział na koszty stałe i zmienne. Zrealizowane w wyniku otrzymanej pomocy projekty rozwojowe, nie miały wielkiego wpływu ani na koszty stałe, ani na koszty zmienne (z pewną 
przewagą zmian w kosztach stałych). Widać więc, iż realizowane projekty, których ostatecznym oczekiwanym przez przedsiębiorców efektem był wzrost zysków (29,7\% przedsiębiorstw odnotowało wzrost zysku po zakończeniu projektu pomiędzy $11 \%$ a $20 \%$; były przedsiębiorstwa, które odnotowały o wiele większe przyrosty zysku brutto, a tylko 5 przedsiębiorstw nie odnotowało w ogóle wzrostu zysku), nakierowane były raczej na maksymalizację przychodów, a nie minimalizowanie kosztów.

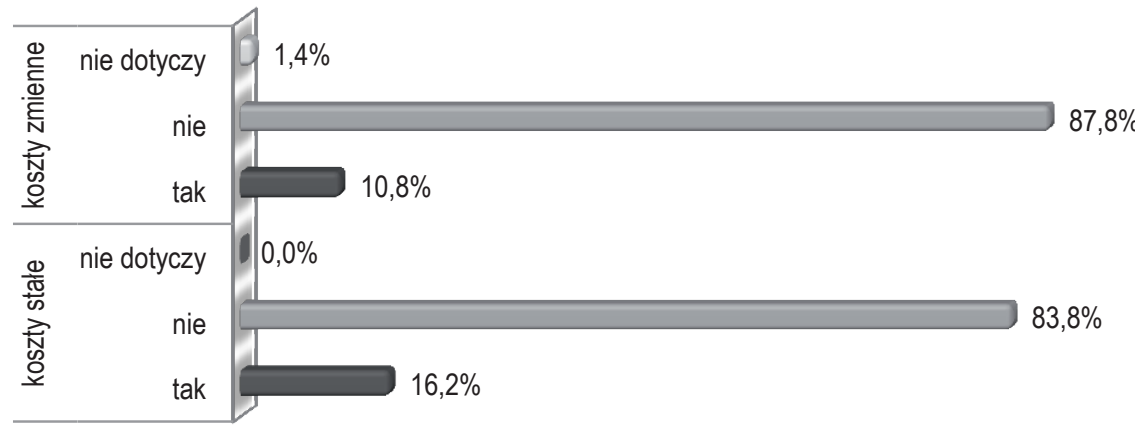

Rysunek 8. Struktura kosztów

Źródło: opracowanie własne na podstawie badań.

Reasumując przeprowadzone badania, stwierdzić można, że niektóre elementy modelu biznesu uległy zmianom w większości przedsiębiorstw. Należą do nich: propozycja wartości (zarówno o charakterze ilościowym, jak i jakościowym), kluczowe zasoby (fizyczne, ludzkie i finansowe) oraz kluczowe działania (poprawa w procesach produkcji). Łącznie więc na te trzy elementy składowe modelu biznesu przypadało 6 charakterystyk, które zmieniły się w większości badanych przedsiębiorstw (tab. 2).

Tabela 2. Zmiany w poszczególnych składnikach modelu biznesu jako efekt otrzymanego wsparcia

\begin{tabular}{|c|c|c|c|}
\hline \multicolumn{2}{|c|}{ Wyszczególnienie } & $0-50 \%$ & $51-100 \%$ \\
\hline \multirow{2}{*}{$\begin{array}{c}\text { Segmenty } \\
\text { klientów }\end{array}$} & dokonano segmentacji klientów & $x$ & \\
\cline { 2 - 4 } & zdywersyfikowano działalność & $x$ & \\
\hline $\begin{array}{c}\text { Propo- } \\
\text { zycja } \\
\text { wartości }\end{array}$ & Zmiany w elementach o charakterze ilościowym & & $x$ \\
\cline { 2 - 4 } & Zmiany w elementach o charakterze jakościowym & & $x$ \\
\hline
\end{tabular}


Cd. tab. 2

\begin{tabular}{|c|c|c|c|}
\hline \multicolumn{2}{|r|}{ Wyszczególnienie } & $0-50 \%$ & $51-100 \%$ \\
\hline \multirow{2}{*}{ Kanały } & utworzono (zmodyfikowano) kanały & $\mathrm{x}$ & \\
\hline & nawiązano kontakty z partnerami & $x$ & \\
\hline \multirow{4}{*}{$\begin{array}{l}\text { Relacje } \\
\text { z klien- } \\
\text { tami }\end{array}$} & wprowadzono (zmodyfikowano) samoobsługę & $x$ & \\
\hline & zautomatyzowano relacje & $\mathrm{x}$ & \\
\hline & $\begin{array}{c}\text { wprowadzono (rozszerzono) współtworzenie pro- } \\
\text { duktów z klientami }\end{array}$ & $\mathrm{x}$ & \\
\hline & osobiste relacje & & \\
\hline \multirow{3}{*}{$\begin{array}{l}\text { Strumie- } \\
\text { nie przy- } \\
\text { chodów }\end{array}$} & wprowadzenie opłaty za korzystanie (abonenckiej) & $x$ & \\
\hline & nowe przychody z udzielania licencji & $\mathrm{x}$ & \\
\hline & wprowadzenie prowizji z tytułu pośrednictwa & $\mathrm{x}$ & \\
\hline \multirow{2}{*}{$\begin{array}{l}\text { Struktura } \\
\text { kosztów }\end{array}$} & obniżenie kosztów stałych & $\mathrm{x}$ & \\
\hline & obniżenie kosztów zmiennych & $\mathrm{x}$ & \\
\hline \multirow{4}{*}{$\begin{array}{l}\text { Kluczowe } \\
\text { zasoby }\end{array}$} & poprawa w zasobach fizycznych & & $x$ \\
\hline & poprawa w zasoby intelektualnych & $x$ & \\
\hline & poprawa w zasobach ludzkich & & $x$ \\
\hline & poprawa w zasobach finansowych & & $\mathrm{x}$ \\
\hline \multirow{3}{*}{$\begin{array}{l}\text { Kluczowi } \\
\text { partnerzy }\end{array}$} & poprawa współpracy z dostawcami & $x$ & \\
\hline & $\begin{array}{l}\text { poprawa współpracy ze współpracującymi przed- } \\
\text { siębiorstwami }\end{array}$ & $x$ & \\
\hline & $\begin{array}{l}\text { poprawa współpracy z inwestorami, kapitałodaw- } \\
\text { cami }\end{array}$ & $x$ & \\
\hline \multirow{3}{*}{$\begin{array}{l}\text { Kluczowe } \\
\text { działania }\end{array}$} & poprawa w procesach produkcji & & $x$ \\
\hline & poprawa w zarządzaniu łańcuchem dostaw & $x$ & \\
\hline & usprawnienia w procesie świadczenia usług & $x$ & \\
\hline
\end{tabular}

Źródło: opracowanie własne na podstawie badań.

Jednocześnie w 6 elementach składowych modelu biznesu dokonano rekonfiguracji u niewielu podmiotów. Takie stwierdzenie jest uzasadnione, 
bowiem należy zwrócić uwagę, iż zastosowany w tabeli 2 podział z przyjętym $50 \%$ kryterium liczebności jest pewnym uproszczeniem rzeczywistości, bowiem w tym przedziale wyniki rozłożyły się w pierwszej części tego przedziału (do 25\%, tzn. nie wystąpiły liczebności pomiędzy $25 \%$ a 50\%).

\section{PODSUMOWANIE}

Zakłada się, iż otrzymana pomoc (szczególnie tak korzystna dla przedsiębiorstw, jak bezzwrotna dotacja), powinna w trwały sposób zmienić logikę oraz zakres funkcjonowania wspartych przedsiębiorstw (a więc powinna zmienić przyjęty $\mathrm{w}$ danym podmiocie model biznesu). $\mathrm{Z}$ przeprowadzonych badań wynika, iż główna składowa modelu biznesu, czyli propozycja wartości, zmieniła się u większości badanych przedsiębiorstw. Jest to zjawisko bardzo korzystne. Oznacza bowiem, iż przedsiębiorstwa zaczęły sprzedawać swoje produkty po atrakcyjniejszych cenach, a przy tym bardziej przydatne dla klientów (np. trwalsze, łatwiejsze w użyciu) i o poprawionej estetyce (np. design). Korzystają na tym sami przedsiębiorcy (pozycja konkurencyjna), jak i klienci (tańszy i lepszy produkt). Większość przedsiębiorstw poprawiła stan kluczowych zasobów, co z punktu widzenia szkoły zasobowej jest korzystne, bowiem pozwala na wykorzystanie okazji pojawiających się w otoczeniu - jak zauważył R. Krupski - z tych samych zasobów można wygenerować wiele produktów i rynków (Krupski, 2014 s. 154). O pozytywnym wpływie zmian w propozycji wartości i kluczowych zasobach przedsiębiorstwa świadczy poprawa osiąganych wyników finansowych (5 badanych przedsiębiorstw nie odnotowało wzrostu zysku brutto, 15 podmiotów odnotowało wzrost w przedziale $1 \%-5 \%$; 18 przedsiębiorstw odnotowało wzrost zysku pomiędzy 6\% a 10\%; u 22 badanych podmiotów wzrost zysku uplasował się pomiędzy $11 \%$ a $20 \%$, u 11 podmiotów było to wzrost pomiędzy $21 \%-100 \%$ i u 3 podmiotów było to powyżej $100 \%$ ). Przy czym u 62 podmiotów był to przyrost sukcesywny, a tylko w 7 podmiotach skok jednorazowy (jako efekt projektu). Jednocześnie w 24 podmiotach nawet po upływie trzech lat od zakończenia projektu mamy do czynienia z dalszymi przyrostami. Widać więc pozytywne efekty w kondycji finansowanej badanych podmiotów. Niemniej jednak niekorzystnym jest fakt braku zmian poprawiających relacje $\mathrm{z}$ otoczeniem. Dotyczy to relacji z klientami, jak i innymi kluczowymi partnerami. Biorąc pod uwagę fakt, że relacje międzyorganizacyjne sprzyjają budowaniu przewagi konkurencyjnej, brak poprawy w tym zakresie jest zjawiskiem niepo- 
kojącym (szczególnie biorąc pod uwagę dłuższy okres, w jakim zamierzają funkcjonować badane przedsiębiorstwa).

\section{LITERATURA}

Aspara J., Lamberg J., Laukia A., Tikkanen H., Corporate Business Model Transformation and Inter-Organizational Cognition: The Case of Noki, „Long Range Planning" 2013, Vol. 46.

Amit R., Zott C., Business Model Design: An Activity System Perspective, „Long Range Planning" 2010, Vol. 22.

Baden-Fuller C., Morgan M., Business models: practice and theory, „Long Range Planning" 2010, Vol. 43.

Casadesus-Masanell R., Ricart J.E., From Strategy to Business Models and onto Tactics, „Long Range Planning” 2010, Vol. 22.

Chesbrough H. Rosenbloom R. S., The role of the business model in capturing value from innovation: evidence from xerox corporation's technology spinoff companies, „Industrial and Corporate Change” 2002, Vol. 11.

Cyfert, S. i Krzakiewicz, K., Wykorzystanie koncepcji modeli biznesu w zasobowej teorii firmy, w: Rozwój szkoły zasobowej zarzadzania strategicznego, red. Krupski R., Prace Naukowe Wałbrzyskiej Wyższej Szkoły Zarządzania i Przedsiębiorczości, Wałbrzych 2011.

Cyfert S., Granice organizacji, Wydawnictwo Uniwersytetu Ekonomicznego w Poznaniu, Poznań 2012.

Modele biznesu w internecie. Teoria i studia przypadków polskich firm, red. Doligalski T. Wydawnictwo PWN, Warszawa 2014.

Falencikowski, T., Spójność modelu biznesu. Koncepcja i pomiar, CeDeWu, Warszawa 2013.

Johnson M., Christensen C., Kagermann H, Reinventing your business model, „Harvard Business Review” 2008, Vol. 86

Krupski R., Koncepcja strategii przedsiębiorstwa z perspektywy zasobowej ukierunkowanej na okazje, w: Zarządzanie strategiczne. Rozwój koncepcji i metod, red. Krupski R., Prace Naukowe Wałbrzyskiej Wyższej Szkoły Zarządzania i Przedsiębiorczości, t. 27, Wałbrzych 2014.

Lambert T., Problemy zarzadzania, Dom Wydawniczy ABC, Warszawa 1999.

Magretta J., Why Business Models Matter?, „Harvard Business Review” 2002, Vol. 80 .

Nogalski B., Karpacz J., Wójcik-Karpacz A., Organizacyjne uczenie się w perspektywie relacji międzyorganizacyjnych, w: Koźmiński A.K., Latusek-Jur- 
czak D., Relacje międzyorganizacyjne w naukach o zarządzaniu, Wolters Kluwer, Warszawa 2014.

Olesiński Z., Zarządzanie relacjami międzyorganizacyjnymi, Wydawnictwo C.H. Beck, Warszawa 2010.

Osterwalder A., Pigneur Y., An e-Bussines Model Ontology for Modeling e-Business, Słowenia:15th Bled electronic commerce conference, 2002.

Osterwalder A., Pigneur, Y., Business Model Generation: A Handbook for Visionaries, Game Changers, and Challengers, John Wiley \& Sons, Inc., Hoboken, New Jersey 2010.

Petrykowska J., Ksztaltowanie relacji z klientami jako podstawa budowania lojalności, w: Ksztaltowanie lojalności konsumenckiej, red. Wiśniewska A., Wyższa Szkoła Promocji, Warszawa 2013.

Prahalad C.K, Ramaswamy V., Przyszłość konkurencji, Polskie Wydawnictwo Ekonomiczne, Warszawa 2005.

Stańczyk-Hugiet, E.I., Dynamika strategiczna w ujęciu ewolucyjnym, Wydawnictwo Uniwersytetu Ekonomicznego we Wrocławiu, Wrocław 2013.

Teece D.J., Business Models, Business Strategy and Innovation, „Long Range Planning" 2010, Vol. 43.

Wikström K., Artto K., Kujala J., Söderlund J., Business models in project business, International Journal of Project Management 2010, Vol. 28.

Zakrzewska-Bielawska A., Ewolucja szkót strategii: przegląd głównych podejść i koncepcji, w: Zarzadzanie strategiczne. Rozwój koncepcji i metod, red. Krupski R., Prace Naukowe Wałbrzyskiej Wyższej Szkoły Zarządzania i Przedsiębiorczości, t. 27, Wałbrzych 2014.

Zott C., Amit R., The fit between product market strategy and business model: implications for firm performance, „Strategic Management Journal” 2008, Vol. 29.

\title{
INVESTMENT GRANTS AS A TOOL FOR MODIFICATION OF BUSINESS MODEL
}

\begin{abstract}
In recent years investment grants have been a popular instrument to support small and medium-sized enterprises, especially within the framework of EU funds. That support was intended to make a fundamental change in the conducted businesses. If you consider that the business model determines the logic of the venture, it should be assumed, that the support should reconfigure business models of surveyed enterprises. Only then you can determine the long-term, positive effects of the support provided.
\end{abstract}

Keywords: business model; small and medium sized enterprises; investment grants. 